\title{
Carry Forward the Spirit of the Constitution, and Comprehensively Promote the Rule of Law Process
}

\author{
Junxing Li \\ Marxism School of Sichuan University, Chengdu Sichuan, 610207, China \\ School of Politics Economics and Management, Zunyi Normal College, Zunyi Guizhou, 563002, \\ China
}

Keywords: The 4th plenary session of the 18th Central Committee, Constitution, Manage the state according to the Constitution, Rule by Constitution.

\begin{abstract}
The 4th plenary session of the 18th Central Committee takes comprehensively promotes the rule of law as the subject to study, highlighting the rule of law in governance modernization role. And to the rule of law, we must carry forward the spirit of the Constitution; give full play to the rule of law in China, the government ruled by law, the role of the constitutional rule of law.
\end{abstract}

\section{Introduction}

The party's eighteen Fourth Plenary Session in China after the reform and opening has entered a crucial phase, in order to carry out and implement the party's eighteen Third Plenary Session on "improvement and development of the socialist system with Chinese characteristics, promote national governance systems and governance modernization" [1] in the context of the overall objective of deepening the reform held, all will comprehensively promote the rule of law as the subject to study, in order to enable all levels of Party committees and governments "to improve the use of the rule of law and the rule of law way of thinking to deepen reform, promote development and resolve conflicts and maintain stability capability, and strive to promote the formation according to the law, failing to find a method to solve the problem of usage, resolve conflicts favorable legal environment by law, to promote the work on the rule of law track. "[2]

\section{Reason to manage the state according to the Constitution and rule by Constitution}

General Secretary Xi Jinping pointed out that "the Constitution is the fundamental law of the country, is bringing peace to the general rules for the rule of law, first, According to the Constitution; Power according to law, it is critical to Rule by Constitution." [2] Why Mr. Xi great emphasis on the Constitution in accordance with the law according to the Constitution and the rule of the ruling in effect? This is mainly due constitutional status and role in the country's decision. Because "the authority to uphold the Constitution, is to maintain the authority of the party and the people's common will. To defend the dignity of the Constitution is to defend the common will of the party and the people's dignity. Ensure implementation of the Constitution, is to ensure the realization of the fundamental interests of the people."

The Constitution is the source of the legitimacy of the ruling Communist Party of China.

Preamble to the Constitution clearly states: "China's new-democratic revolution and the socialist cause have been achieved, the Chinese Communist Party led the Chinese people of all nationalities in Marxism-Leninism, Mao Zedong Thought under the guidance of, upholding truth and rectifying mistakes, overcome many difficulties and obstacles acquired." [3] This is to show the world the Chinese Communist Party leadership in the country is not self-appointed, but to the Chinese nation and the liberation and happiness of the Chinese people, through their own hard work, paid a huge sacrifice, It has been recognized by the people after the formation, the source of the legitimacy of the ruling.

The Constitution has unlimited authority.

As the fundamental law of the state, the constitution is the higher law of all laws and regulations, which has unlimited authority. Preamble of the Constitution states: "This Constitution, in legal form, 
affirms the achievements of the struggles Chinese people of all nationalities and defines the basic system and basic tasks of the State, is the fundamental law of the state and has supreme legal authority people of all nationalities, all state. organs and armed forces, all political parties and social organizations, enterprises and institutions, must take the Constitution as the basic guidelines and the duty to uphold the dignity of the Constitution and ensure its implementation of the Constitution. "[3] the preamble to the Constitution that we want to achieve improvement and development of the socialist system with Chinese characteristics, promote national governance systems and governance modernization of this goal, we must uphold the people's democratic dictatorship and the socialist system constitutional, must adhere to the basic national conditions of the primary stage of socialism, the Communist Party of China under the leadership to achieve the great rejuvenation of the Chinese dream as a guide, in coordination to promote the "four comprehensive" process, adhere to the path of self-confidence, the theory of self-confidence, confidence in the system, do not toss, do not slack off, team work and orderly socialism modernization, to achieve a prosperous, democratic, civilized and harmonious nation.

\section{Constitution embodies the pursuit of human values.}

Constitution of human history is a history to liberate them. From 1215 "Magna Carta" British start to 1776, the United States 'Declaration of Independence', 1789 French "Declaration of human and civil rights" to the 1918 first Soviet Constitution, as human rights manifesto, regardless of the Constitution or the Constitution of the proletariat the bourgeoisie, they are imbued with democracy, the rule of law, principles of human rights, as human beings constitution when the pursuit of eternal values theme. As human civilization advanced inheritance and development, our Constitution also fully embodies the pursuit of these values.

\section{1) Democratic principles}

Article II of the Constitution says: "All power in the People's Republic of China belongs to the people. The people exercise state power is the National People's Congress and local people's congresses. People accordance with the law, through various channels and forms, management of national affairs, manage economic and cultural undertakings and social affairs. "[3] this provision not only pointed out the state power comes from the people, who are the subject of state power, but also defines the people exercise power and authority to exercise the powers of the range, fully embodies democratic principle of popular sovereignty.

2) Principle of rule of law

"People's Republic of China Constitution positive case" in March 1999 by the Ninth National People's Congress of China adopted in Article V of the rule of law and building a socialist country ruled by law into the Constitution. Also provides that "all laws, administrative regulations and local regulations may contravene the Constitution. All state organs and armed forces, all political parties and social organizations, enterprises and institutions must abide by the Constitution and the law. All acts in violation of the Constitution and the law acts must be investigated. no organization or individual may go beyond the Constitution and the law of privilege. "[3] this provision is not only the rule of law as the basic strategy of the party governing the country in the Constitution, and the Constitution and laws in the country positions of authority were clearly described in our socialist modernization process, absorb and learn from the results of political civilization of mankind has made significant progress in the modernization of national governance.

3) Human rights principle

Human Rights also called citizens' basic rights and civil rights, as the basic human rights of citizens of the modern state owned. 1982 Constitution conscientiously sum up the previous constitution on the basis of lessons learned, combined with the new era, the fundamental rights of citizens made a major adjustment and enrichment. These basic rights include the rights and freedoms of citizens to participate in political life; rights of specific persons (women, retirees and rights of revolutionary martyrs; liberty and freedom of belief of citizens; the right to social, economic, educational and cultural aspects of the citizens; protection of marriage, family, mothers, children and the elderly, care and development of young children, the rights of overseas Chinese). Especially the "People's Republic of China Amendment to the Constitution," in March 2004 of the Tenth National 
People's Congress adopted the "the state respects and safeguards human rights" as the basic rights of citizens be prescribed more highlighted the respect and guarantee the fundamental rights of the citizens of the country can not shirk its statutory obligations.

\section{4) Constitution embodies the national organization}

Chapter III of the Constitution devoted to national institutions provisions. China's national organization includes both central and local levels. Central levels include National People's Congress, Chairman of the People's Republic of China, the State Council and the Central Military Commission. Local level includes local People's Congresses and Local governments, autonomous areas, the people's courts and people's procuratorates. At the same time, the Constitution also defined the status and role of various organizations in the country in the organization. These provisions help people through various national organizations to implement and maintain their own interests.

\section{How to manage the state by the Constitution and how the rule the state by the Constitution}

\section{Build a legal country.}

1) Public servants must have awe, gratitude, loyalty to people

The Constitution clearly stated that all state power belongs to the people. This requires national public officials to bear in mind that they are servants of the people, understand their own power is given by the people, the people is their god, the people have the awe, gratitude, loyalty means. To always remember the purpose of the party serving the people wholeheartedly, thinking problems, making decisions, doing things, should be from the perspective of the people, truly right of the people, benefits for the people, for the love the people of the Department, should always be the safety and well-being of the people in mind, the people 's support, agree or disagree, happy or not, accept or not "as to the problem, starting point and end of their careers, like love yourself parents as for the people's interests, the people ran with a good life, must not be superior, fish people. Take an oath to the Constitution in mind.

2) Correctly handle the relationship between the party and the law

The rule of law is a major strategy of the Communist Party of China in the development of world politics civilization absorption process of governance, and this strategy will determine the success, we need to correctly handle the relationship between the Party and the law. On the one hand, the Constitution and laws are developed under the leadership of the party, which focused on the wisdom of the Party and the people, reflect the aims and tasks of the national nature of our country and the Chinese Communist Party. On the other hand, the Party led the people to develop not only the Constitution and laws, and the Party must lead the people to abide by the Constitution and laws, so that their activities within the framework of the Constitution and laws, and can not arbitrarily violate the Constitution and laws. This shows that the Party and the Constitution and laws closely intrinsically linked, the two can not be completely separated. Therefore, in promoting the Rule of Law in the process, we have to be closely linked to the party and the law, and not be able to party and legal opposition, blindly copying Western Constitution and laws, to engage in "separation of powers", the "big party or big law "such pseudo proposition pointless discussion. The only way to fully protect both the Chinese Communist Party leadership in the country this Constitution, the independence of the judiciary while also supports the trial according to the law and can not interfere in the work of the judiciary, judicial intervention of the leadership will be held accountable.

3) To increase the implementation of the constitution supervision, the establishment of accountability mechanisms unconstitutional

"Life and the authority of the Constitution lies in the implementation." [2] While we have always said that the Constitution is the fundamental law of the country, but in reality it is more difficult to implement, the root cause is not established constitutional litigation system, form a complete system of constitutional review. The Constitution of the prosecution in the world can be described as a long history. As early as in 1803 case of Marbury v. Madison, the United States formally established the constitutional litigation system in order to defend the rights of the original and supreme will of the people. Britain's parliament has been exercising the judicial power is constitutional litigation. In 1920, Austria took the lead in the establishment of the Constitutional Court of the European continent, thus 
creating a constitutional litigation Kelsen model. After World War II, Europe is set off a wave of establishment of the Constitutional Court climax. As in 1946, France established the Constitutional Council, established in 1947, the Italian Constitutional Court, established in Switzerland by the Federal Court to exercise jurisdiction over constitutional litigation, Germany and Hungary in 1949 to establish a constitutional court. Under the influence of the United States and Europe, many Asian countries have begun to establish a system of constitutional litigation, in 1946 and 1947, Japan and India, respectively, the provisions of the Constitution the Supreme Court exercise judicial proceedings; establishment of the Constitutional Court of South Korea in 1988; Thailand in 1991 arbitration committee was established in the Constitution. Today, the state of the rule of law basically established constitutional litigation, and put it as an institutional arrangement. Therefore, comprehensively promote the rule of law in the process, we need to draw on the establishment of constitutional litigation overseas institutional arrangements, by strengthening the constitutional oversight mechanisms to strengthen the implementation of the constitution, and enable the unconstitutional legal sanctions, which truly reflects the constitutional position in the countries.

\section{Construct a law-based government.}

Rule by law is an important part of the rule of law. The so-called rule of law at all levels of government that government officials can be exercised within their respective duties and powers conferred powers of national laws and regulations, neither the absence nor offside, but can not use their power to seek personal gain. In other words, the rule of law the government's goal is to be able to all levels of government administration according to law. The key administration according to law is in accordance with the Constitution the executive. This needs to raise awareness of the Constitution of the State civil servants, especially leading cadres. Because the Constitution is the foundation, starting point is thinking the rule of law thinking. We need to study constitutional thinking, solve major constitutional issues facing the development of Chinese society, the rule of law thinking, the rule of law to resolve various social contradictions. Thus, the rule of law the government, the laws and regulations necessary to use standardized operation mechanisms at all levels of government, the government officials and the governing power to unify, both to prevent officials use their public power for personal gain, but also to ensure that officials have made clear their responsibilities, both diligent conduct of public affairs, without arbitrary interference private rights of citizens. Because the abuse of public power is evil, government power is constrained by the laws and regulations necessary for the good.

\section{Construct society with rule of law.}

"The foundation of constitution of is the support from the people, and the great power of constitution is the sincere faith from people" [2] whether the concept of the Constitution can be recognized by the people, and we need to focus on the rule of law according to the Constitution and the rule of law in society so that people consciously observe and apply the Constitution and laws of social life. The so-called rule of law is a rule-based, pay attention to the order of society. The rule of law has three basic features, one openness. Rules rule of law by the state to the public explanation by laws and regulations. The second is fairness. Rules of the rule of law are the same for everyone. Third, impartiality. The rule of law in the application of laws and regulations, all are equal. Thus, the rule of law, not only government administrations according to law, citizens have to establish the habit of abiding by the law. Both the Constitution and the law enjoy their rights, but also to fulfill the obligations of the Constitution and the law. In this way, people can break the rules in the public service by the relationship, by transfer of benefits and other unspoken rules, so that the credibility of the government has been effectively demonstrated that people's interests are effectively maintained so that the public interest is effectively implemented, ultimately, to the highlight the dignity, to harmonious functioning of society.

\section{References}

[1] Official Gazette of The 4th plenary session of the 18th Central Committee (full text), Radio.cn, Nov.12, 2013 
[2] Xi Jinping: Speech in constitution promulgated 30 years' ceremony. Dec. 4, 2012. Xinhuanet [3] Constitution of the People's Republic of China. www.npc.gov.cn. 